ТЕОРІЯ І МЕТОДИКА ПІДГОТОВКИ

СПОРТСМЕНІВ

\title{
MODELING OF THE COMPETITIVE ACTIVITY OF HIGHLY QUALIFIED FEMALE ATHLETES SPECIALIZING IN MODERN PENTATHLON
}

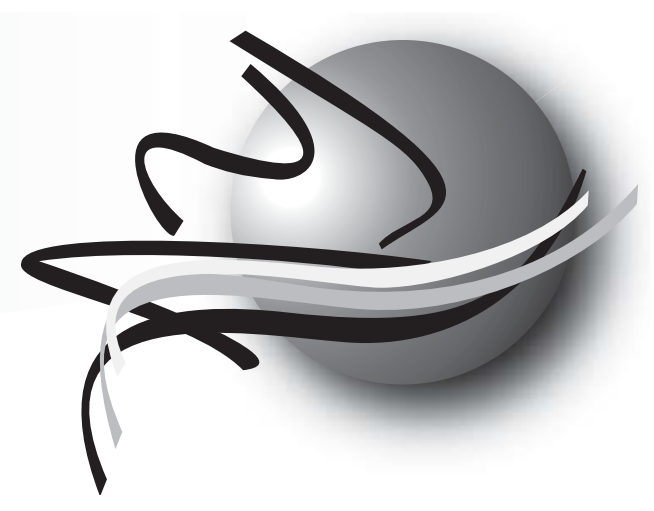

\author{
Sevdalev Sergey ${ }^{l}$,Vrublevskiy Evgeniy ${ }^{1,2}$, Aleinik Evgeniy ${ }^{l}$ \\ ${ }^{1}$ Educational Establishment «Francisk Skorina Gomel State University» \\ ${ }^{2}$ University of Zielona Góra
}

DOI: 10.32540/2071-1476-2021-3-109

\section{Annotation}

Introduction. At present, a fairly effective domestic system of sports training in modern pentathlon has been formed. However, the growth of sports results and the changing rules of competitions require specialists in the field of sports science, coaches and athletes to search for new effective ways to improve the system of training pentathletes. Management of the training process of highly qualified athletes specializing in modern pentathlon is possible by structuring it, based on the analysis of the results of the competitive activity of leading athletes.

The purpose of the study is to develop models of competitive activity of the strongest athletes in the world who specialize in modern pentathlon. The set of methods used to solve the tasks included: theoretical analysis and generalization of scientific and methodological literature data, analysis of the protocols of competitions of the world championships, the finals of the world cup in modern pentathlon since 2014 and the 2016 Olympic Games, modeling and forecasting, methods of statistical processing of the received material.

Results. The analysis of the performances of highly qualified athletes-pentathletes at the largest tournaments made it possible to build a generalized model of competitive activity. This model can be used when planning basic, versatile training. Two types of group models of competitive activity in modern pentathlon have been determined. The first type is typical for a group of athletes who are mainly able to achieve high results in fencing, distinguished by a high level of speed-power and coordination abilities. The second one unites athletes who achieve high results in the combined type of modern pentathlon. Athletes whose competitive activity corresponds to the second type are inferior to the representatives of the first in the manifestation of speed-power potential and the development of coordination abilities, but they significantly surpass them in endurance.

Conclusions. The analysis of model characteristics made it possible to recommend that specialists, coaches and athletes, while improving the pentathlon training system, pay special attention to fencing and increasing the effectiveness of running training, which, in connection with the upcoming changes in the rules of the competition, can become a reserve for further growth of sports results. In this case, it is necessary to take into account the individual characteristics of a particular multisport and rely to a greater extent on its leading motor abilities. Such an organization of the training process, based on the constant consideration of the individual characteristics of each athlete, is most justified at the stage of higher sports achievements.

Keywords: competitive activity, sports training, modeling, modern pentathlon, highly qualified athletes, fencing, swimming, horse riding, combined type

\section{Анотація}

Вступ. В даний час сформувалася досить ефективна вітчизняна система спортивної підготовки в сучасному п'ятиборстві. Однак зростання спортивних результатів, правила змагань що змінюються вимагають від

(C) Sevdalev S.,Vrublevskiy E.,

Aleinik E., 2021 
фахівців в області спортивної науки, тренерів і спортсменів подальшого пошуку нових ефективних шляхів вдосконалення системи підготовки п'ятиборців. Управління тренувальним процесом висококваліфікованих спортсменів, що спеціалізуються в сучасному п'ятиборстві, можливо шляхом його структурування, заснованого на аналізі результатів змагальної діяльності провідних спортсменів.

Мета дослідження - розробити моделі змагальної діяльності найсильніших спортсменок світу, що спеціалізуються в сучасному п'ятиборстві. Сукупність методів, що використовуються для вирішення поставлених завдань, включала: теоретичний аналіз та узагальнення даних науково-методичної літератури, аналіз протоколів змагань чемпіонатів світу, фіналів кубка світу з сучасного п'ятиборства, починаючи з 2014 року, та Олімпійських ігор 2016 року, моделювання та прогнозування, методи статистичної обробки отриманого матеріалу.

Результати дослідження. Проведений аналіз виступів висококваліфікованих спортсменів-п'ятиборців на найбільших турнірах дозволив побудувати узагальнену модель змагальної діяльності. Дана модель може використовуватися при плануванні базової, різнобічної підготовки. Визначено два типи групових моделей змагальної діяльності в сучасному п'ятиборстві. Перший тип характерний для групи спортсменів, здатних переважно досягати високих результатів у фехтуванні, що відрізняються високим рівнем швидкісно-силових і координаційних здібностей. Другий об'єднує спортсменів, що досягають високих результатів в комбінованому вигляді сучасного п'ятиборства. Спортсмени, змагальна діяльність яких відповідає другому типу, поступаються представникам першого в прояві швидкісно-силового потенціалу і розвитку координаційних здібностей, але вони значно перевершують їх у витривалості.

Висновок. Аналіз модельних характеристик дозволив рекомендувати фахівцям, тренерам і спортсменам при вдосконаленні системи підготовки п'ятиборців особливу увагу приділяти фехтуванню і підвищенню ефективності бігової підготовки, яка, у зв'язку з майбутніми змінами правил проведення змагань, може стати резервом подальшого зростання спортивних результатів. При цьому слід враховувати індивідуальні особливості конкретної багатоборки і в більшій мірі спиратися на іїі провідні рухові здібності. Така організація тренувального процесу, заснована на постійному обліку індивідуальних особливостей кожної спортсменки, є найбільш виправданою на етапі вищих спортивних досягнень.

Ключові слова: змагальна діяльність, спортивна підготовка, моделювання, сучасне п'ятиборство, висококваліфіковані спортсменки, фехтування, плавання, верхова їзда, комбінований вид.

\section{Аннотация}

Введение. В настоящее время сформировалась достаточно эффективная отечественная система спортивной подготовки в современном пятиборье. Однако рост спортивных результатов, изменяющиеся правила соревнований требуют от специалистов в области спортивной науки, тренеров и спортсменов дальнейшего поиска новых эффективных путей совершенствования системы подготовки пятиборцев. Управление тренировочным процессом высококвалифицированных спортсменов, специализирующихся в современном пятиборье, возможно путем его структурирования, основанного на анализе результатов соревновательной деятельности ведущих спортсменов.

Цель исследования - разработать модели соревновательной деятельности сильнейших спортсменок мира, специализирующихся в современном пятиборье. Совокупность методов, используемых для решения поставленных задач, включала: теоретический анализ и обобщение данных научно-методической литературы, анализ протоколов соревнований чемпионатов мира, финалов кубка мира по современному пятиборью, начиная с 2014 года, и Олимпийских игр 2016 года, моделирование и прогнозирование, методы статистической обработки полученного материала.

Результаты исследования. Проведенный анализ выступлений высококвалифицированных спортсменов-пятиборцев на крупнейших турнирах позволил построить обобщенную модель соревновательной деятельности. Данная модель может использоваться при планировании базовой, разносторонней подготовки. Определены два типа групповых моделей соревновательной деятельности в современном пятиборье. Первый тип характерен для группы спортсменов, способных преимущественно достигать высоких результатов в фехтовании, отличающихся высоким уровнем скоростно-силовых и координационных способностей. Второй - объединяет спортсменов, достигающих высоких результатов в комбинированном виде современного пятиборья. Спортсмены, соревновательная деятельность которых соответствует второму типу, уступают представителям первого в проявлении скоростно-силового потенциала и развитии координационных способностей, но они значительно превосходят их в выносливости.

Выводы. Анализ модельных характеристик позволил рекомендовать специалистам, тренерам и спортсменам при совершенствовании системы подготовки пятиборцев особое внимание уделять фехтованию и 
повышению эффективности беговой подготовки, которая, в связи с предстоящими изменениями правил проведения соревнований, может стать резервом дальнейшего роста спортивных результатов. При этом следует учитывать индивидуальные особенности конкретной многоборки и в большей мере опираться на ее ведущие двигательные способности. Такая организация тренировочного процесса, основанная на постоянном учёте индивидуальных особенностей каждой спортсменки, является наиболее оправданной на этапе высших спортивных достижений.

Ключевые слова: соревновательная деятельность, спортивная подготовка, моделирование, современное пятиборье, высококвалифицированные спортсменки, фехтование, плавание, верховая езда, комбинированный вид.

\section{Introduction.}

In recent years, the interest of specialists in the analysis of the specifics of competitive activity has increased, the study of which in individual sports has been given a lot of attention in the special literature $[1,2]$. However, the information related to this aspect in complex types of competitions - all-round events, which are distinguished by an extraordinary variety and complexity of requirements for the manifestation of special physical, technical, tactical and psychological readiness of athletes [3] is clearly insufficient.

The issues of studying the structure of various aspects of the training of athletes specializing in various types of complex all-round events have recently received much attention. This is due to the search for ways to optimize the training process control system, based on identifying the strengths and weaknesses of readiness and timely correction of training influences. So, the development of models of athletes heptathlon of various levels of fitness and their model characteristics for improving the training management system in his works was considered by V.M. Mikhailov. [4]. He proved that the practical application of models of competitive activity and characteristics of special physical and technical readiness of women, specializing in athletics all-around, helps to optimize the management of the training process of female athletes of various qualifications and, ultimately, to the effective growth of sports results.
T. Gabrys [5] devoted his research to finding differences in the structure of long-term training of women in athletics all-around from the training of men in decathlon at the age from 11 to 24 years. He found that in women and men, the importance of speed species and their contribution to the final result increases with age; among boys from 11 to 17 years old, the rate of increase in speed is constant $(6.60 \%)$, among girls, there is a decrease in the rate of growth of this indicator (from 5.69\% to $1.85 \%$ ); decathletes aged 15-17 achieve high sports results due to increased readiness in certain types of all-around, among girls at this age, sportsmanship grows by achieving high results in all types of all-around, which necessitates differentiation of methods, means, volumes and intensity of the training load.

S.M. Sukhanov [6] analyzed the results of the 25 strongest athletes in the heptathlon of the World and Russia. When considering the relationship between the sum of points in the athletics heptathlon and the results in certain types of all-around in the groups of Russian athletes and the best athletes in the World, it was found that a higher correlation was observed with the result in the $100 \mathrm{~m}$ hurdles and long jump, a strong relationship was also revealed between the sum of points and the result in the shot put in the strongest all-round competitions of the World and Russia.

Ukrainian Natalia Dobrynskaya analyzed the competitive activity of outstanding heptathlon women
- owners of gold, silver and bronze medals at the 1988-2012 Olympics. Her research showed that female athletes can be divided into several independent groups [7]:

1) those who achieve high sports results mainly in athletics throw, this group includes $33 \%$ of athletes;

2) those who achieve high sports results mainly in the running types of the program ( $29 \%$ of athletes);

3) those who achieve high sports results in the athletics heptathlon, mainly in jumping and hurdling (33\% of athletes).

In the women's heptathlon, O.B. Nemtsev reviewed the results of the first 100 heptathies from the world top lists of 2000 and 2016. It was determined by him that modern allaround athletes strive to improve their results in the heptathlon by increasing the results in the 100 meters hurdles and 200 meters [8].

V.V. Mekhrikadze studied the specificity of the relationship between progress in a separate form (group of types) heptathlon with progress in the sum of the allaround. The extreme values of the variation series built for each type of heptathlon (strong and weak results of the species) were investigated. The comparative analysis of the results of "leaders" and "outsiders" in each type of heptathlon, carried out by him, revealed the essence of the interrelationships of types among highly qualified athletes, made it possible to identify the types (combinations of types) that determine the decisive growth of the results of the final sum. [9]. 
Freya Gassmann [10] carried out a statistical analysis of the results of the all-around 10 strongest heptathlon athletes of the World Championships and the Olympic Games. She proposed to classify the heptathlon into "Specialists" and "Universal". According to her data, "Specialists" are found more often than "Universal" by $12 \%$. F.Gassmann argues that the result in the long jump in the heptathlon of women is of paramount importance, which is reflected in the high degree of accuracy of the variance of $48 \%$ and is explained by the high degree of interconnection with the disciplines of 100 meters with hurdles, high jumps and 200 meters running.

In the process of analyzing the special literature available to us, we were able to mainly identify scientific works considering competitive activity in athletics all-around, only a small number of works are devoted to the analysis of competitive activity in other types of all-around events. So, the work of Sevdalev S.V. is devoted to the peculiarities of the structure of competitive activity and intergroup differences among elite athletes specializing in modern pentathlon. [11].

G.I. Narskin, S.V. Sevdalev [12], in their research, determined the specifics of the competitive activity of highly qualified athletes specializing in modern pentathlon based on the results of the Cup of the Republic of Belarus in 2021 and the World Cup in 2019.

A. I. Sergeev was engaged in research of long-term practice of sportswomen's competitive activity in service-applied types of all-round events. He revealed the specificity of competitive activity, determined in percentage terms the contributions of each type of biathlon to the overall result, depending on the qualifications of the athletes. It was determined that the effectiveness of the performances of qualified sportswomen in the service-applied types of all-around is conditioned by the use of a rational combination of the volumes of training means in the educational-training process, on the basis of taking into account the specifics of this type of all-around [13].

Thus, in order to create a promising individual model of competitive activity, it is necessary to determine its individual indicators based on the analysis of competitive activity. The obtained data are compared with generalized and group models of competitive activity of highly qualified athletes, and on this basis, the strong and weak types of an athlete are determined

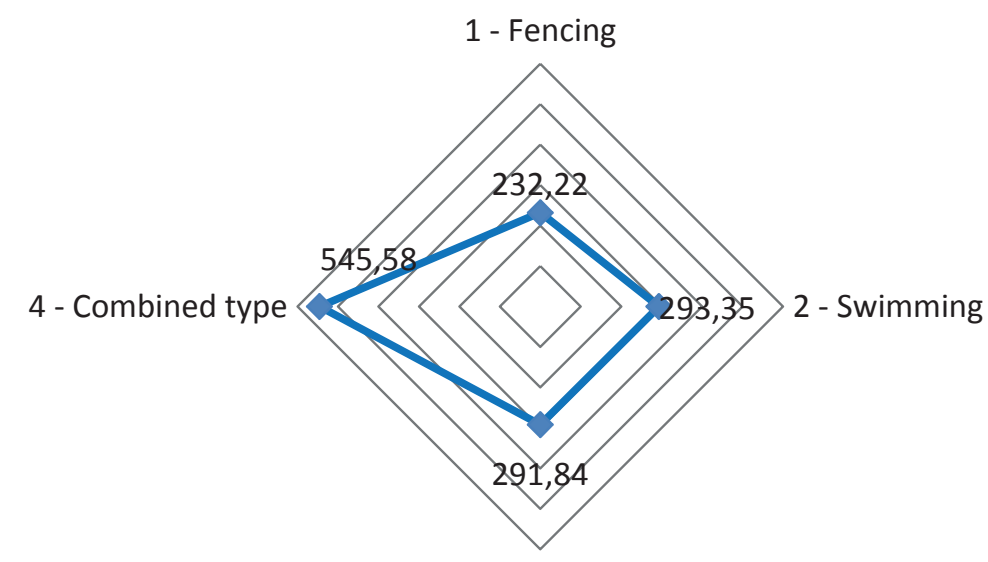

3 - Horse riding

Fig. 1. Generalized model of competitive activity of highly qualified sportswomen in modern pentathlon. and the reserves for further sports improvement are revealed. Modern pentathlon is one of the complex types of sports all-around. To achieve a high result, a rational combination of the amount of funds aimed at improving in certain types is necessary. Effective planning of training in modern pentathlon, in our opinion, will be facilitated by informative analytical data characterizing the relationship between the results in certain types of pentathlon with the overall competitive achievement

\section{Hypothethis.}

It was assumed that the construction of models of competitive activity would make it possible to bring the content of the training process into conformity, which initiates a methodology that presupposes the unity of the structure of competitive activity and the structure of athletes' fitness. Therefore, information about the activities of an athlete at competitions, under certain conditions, can serve as a basis for setting goals and objectives of training, choosing the means and methods of their implementation.

The purpose of the study is to develop models of competitive activity of the strongest athletes in the world, specializing in modern pentathlon.

Research methods. The set of methods used to solve the assigned tasks included: theoretical analysis and generalization of scientific and methodological literature data, analysis of the protocols of the competitions of the world championships, the finals of the world cup in modern pentathlon since 2014 and the 2016 Olympic Games, modeling and forecasting, methods of statistical processing of the received material.

\section{Research results.}

It should be noted that, according to the authors $[2,7,14,15,16]$, the training of qualified athletes involves the use of modeling. Its most important element in modern sports is the modeling of competitive

(C) Sevdalev S.,Vrublevskiy E., Aleinik E., 2021 


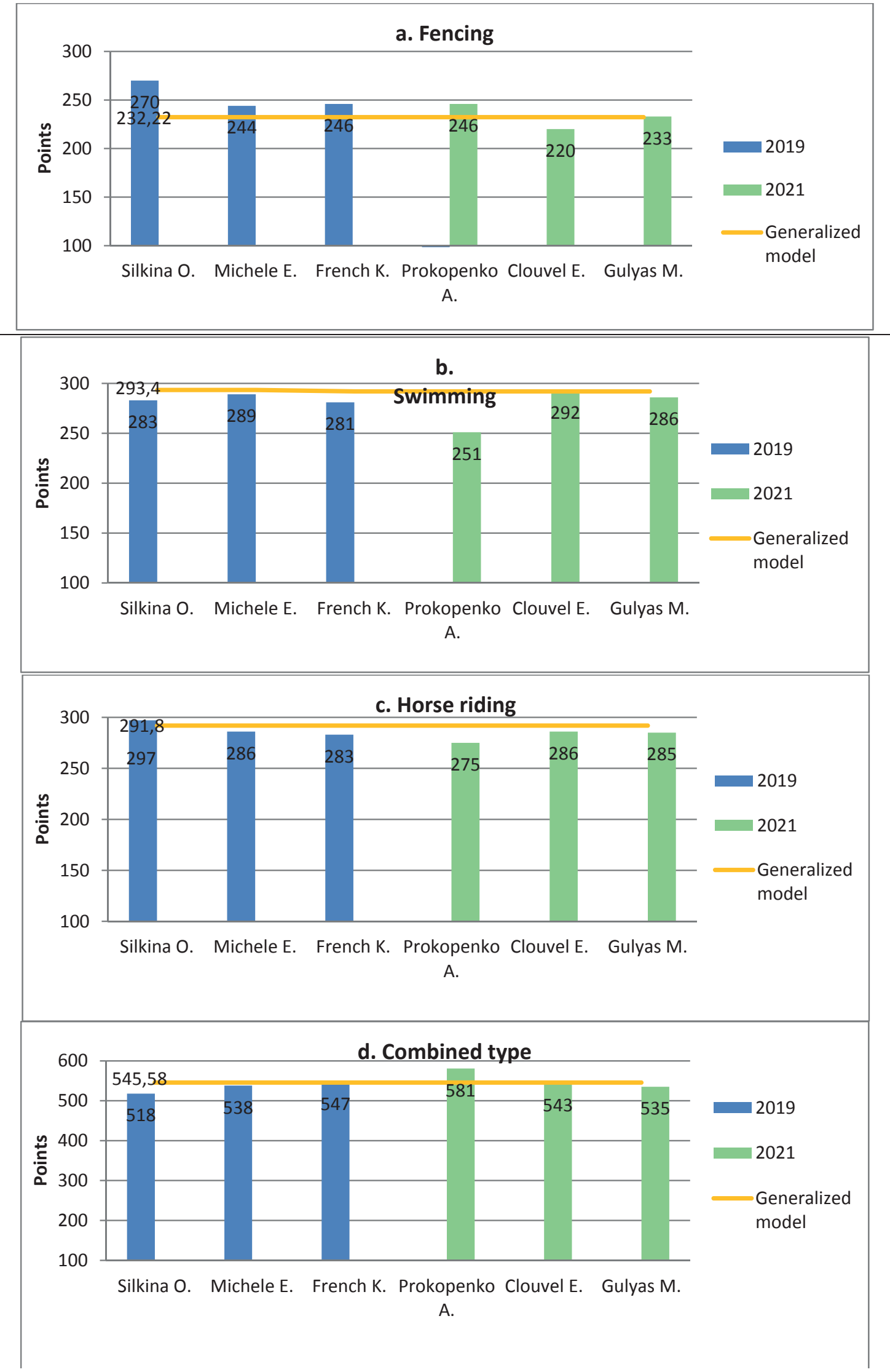

Figure 2 - Model and individual characteristics competitive activity of highly qualified female athletes specializing in modern pentathlon (a.- fencing, b.- swimming, c.- horse riding, d.- combined type)

(C) Sevdalev S.,Vrublevskiy E., 


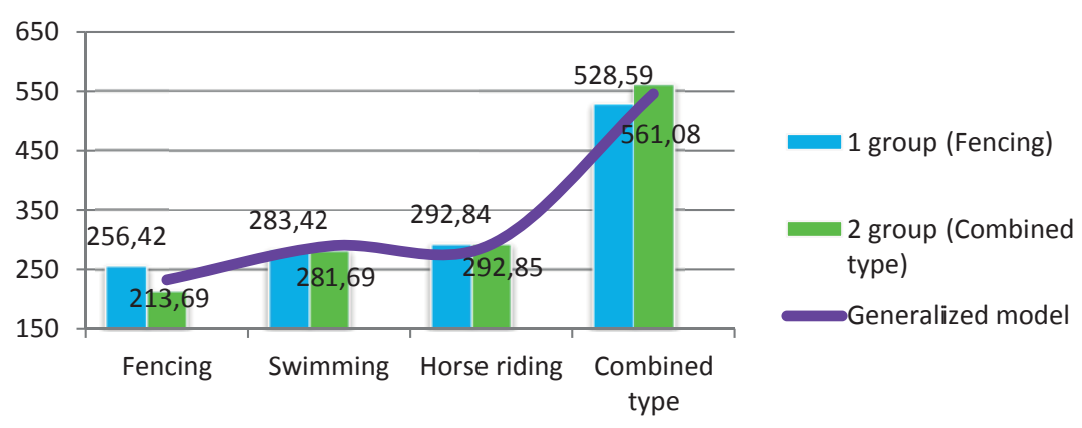

Fig. 3 Group characteristics of the competitive activity of highly qualified pentathletes, in comparison with the generalized model

activity, its quantitative and qualitative characteristics, ensuring the achievement of the planned results. This type of modeling predetermines the content of the training process. When forming models of competitive activity, one should focus on the characteristics that are most significant for achievements in a particular type of competition.

In the types of sports all-around, the authors suggest using three types of models: generalized, group, individual [7]. Generalized models have an average character and reflect the competitive activity of a large group of athletes and, according to the authors [7], can be used when planning a versatile training. Group models reflect the predisposition of a number of athletes to high results in certain types of all-around, which allows to form individual models of competitive activity with great accuracy, and thus individualize sports training

Based on the analysis of the results shown by the winners and prize-winners of the World Championships (WCH), the World Cup Finals (FCF) and the Olympic Games (OG) since 2014 (the average results shown by athletes in certain types), a generalized model of the competitive activity of highly qualified athletes specializing in modern pentathlon was built

Figure 1 shows the average results (in points) shown by athletes in the types of modern pentathlon: 1 - fencing, 2 - swimming, 3 - horse riding, 4 - combined type.

In the process of research, it was determined that reaching the level of 1363 points in the implementation of the generalized model is provided by the following indicators: fencing - 232.22; swimming - 293.35; horse riding - 291.84; combined type -
545.58 points.

A comparative analysis of the model and individual characteristics of the competitive activity of the winners and prize-winners of the last world championships revealed that the athletes who show the highest final results in one of the all-around types, as a rule, become winners.

Thus, a comparative analysis of the individual and model characteristics of the world championship winners showed that Michelie (Figure 2a.) exceeded the generalized indicators in fencing by $5.07 \%$. The 2019 world champion O. Silkina exceeded the model indicators in fencing by $16,27 \%$ (figure 2a.) and horse riding by $1,78 \%$ (figure 2c.). The results of French K. exceed the model indicators in fencing by $5.93 \%$ (Figure 2a.), combined by $0.26 \%$ (Figure 2d.). The world champion in 2021 A. Prokopenko exceeds the generalized indicators in the combined type by $6.49 \%$ (Figure 2d.) and fencing by $5.93 \%$ (Figure 2a.), while being significantly inferior in swimming and horse riding $-6.89 ; 6.11 \%$, respectively (figure 2b, c). Clouvel E. almost reached all generalized indicators, with the exception of swimming (Figure 2b.). The medalist of the 2021 World Championship Gulyas M. achieved generalized indicators in fencing (Figure 2a.), yielding to the average indicators in other

Table 1

Correlation relationship ( $\rho$ ) between the places occupied by athletes in certain types of modern pentathlon and their final place in the final competitions. (World Championship Budapest 2019, $n=36$ )

\begin{tabular}{|c|c|c|c|c|}
\hline Type of modern pentathlon & Final place & Fencing & Swimming & Horse riding \\
\hline Final place & 1,000 & & & \\
\hline Fencing & 0,737 & 1,000 & & \\
\hline Swimming & 0,394 & 0,182 & 1,000 & \\
\hline Horse riding & 0,342 & $-0,019$ & 0,065 & 1,000 \\
\hline Combined type & 0,538 & $-0,023$ & 0,025 & 0,301 \\
\hline
\end{tabular}

Note. Coefficients with statistically significant (at $\mathrm{p}<0.05$ ) correlation are marked in bold. 
Correlation relationship ( $\rho$ ) between the places occupied by athletes in certain types of modern pentathlon and their final place in the final competitions. (World Championship, Cairo 2021, $n=36$ )

\begin{tabular}{|c|c|c|c|c|}
\hline Type of modern pentathlon & Final place & Fencing & Swimming & Horse riding \\
\hline Final place & 1,000 & & & \\
\hline Fencing & 0,514 & 1,000 & & \\
\hline Swimming & 0,343 & $-0,054$ & 1,000 & \\
\hline Horse riding & 0,435 & 0,064 & 0,238 & 1,000 \\
\hline Combined type & 0,801 & 0,076 & 0,180 & 0,240 \\
\hline
\end{tabular}

Note. Coefficients with statistically significant (at $\mathrm{p}<0.05$ ) correlation are marked in bold.

events (Figure 2b, c, d.).

Analyzing the performances of the strongest athletes specializing in modern pentathlon $(n=45$, winners and prize-winners of Olympic Games, World Championships, the World Cup Finals), based on the generalized model of competitive activity, several groups of athletes with a similar structure of competitive activity can be distinguished (Figure 3).

The first type is typical for a group of athletes who are able to predominantly achieve high results in fencing $(\mathrm{n}=12 ; 26.67 \%$, Fig. 3 , group 1), which may indicate their high level of speed-power and coordination abilities.

The second one unites athletes who achieve high results in the combined type of modern pentathlon $(\mathrm{n}=14 ; 31.11 \%$, Fig. 3, group 2). Athletes whose competitive activity corresponds to the second type are inferior to the representatives of the first in terms of speed-power potential and the development of coordination abilities, but they significantly surpass them in the manifestation of endurance.

In modern women's pentathlon, it is also possible to distinguish small groups of athletes who achieve high performance in fencing and swimming $(\mathrm{n}=2$; $4.44 \%)$, swimming $(n=5 ; 11.11 \%)$, swimming and combined sports (n $=4 ; 8.89 \%$ ), fencing and combined type $(n=4 ; 8.89 \%)$, the insignificant representation of athletes in these groups does not allow them to be singled out as a separate one. The results of one athlete exceeded the model indicators in all types of all-around $(\mathrm{n}=1 ; 2.22 \%)$; one athlete did not exceed the average indicators in fencing, combined type and swimming $(\mathrm{n}=1 ; 2.22 \%)$. We also investigated (using Spearman's rank correlation coefficient) the correlation relationship between the final place of athletes in modern pentathlon and the places they occupied in some of its types (World Cup 2019, 2021, Tables 1-2).

Analyzing the matrix of rank correlation coefficients, built on the basis of the results of the 2019 World Cup, it should be noted that there is a statistically significant correlation between the final result and the results in each of the types of modern pentathlon. Thus, a high correlation was revealed between the final result (place) and the place occupied in fencing $(\rho=$ 0.737), a noticeable correlation between the final result and the place in combined type $(\rho=0.538)$, a moderate correlation between the final place and place, engaged in swimming $(\rho=0.394)$ and a moderate relationship between the final place and the place of horse riding $(\rho=0.342)$.

The participants of the 2021 World Championship (Table 2) showed a high positive correlation between the final place and the place occupied in the combined type
( $\rho=0.801)$, a noticeable correlation between the final place and the place occupied in fencing $(\rho=0.514)$, and horse riding $(\rho=0.435)$. A weak positive relationship was found between the final place of the athlete and the place occupied by him or her in swimming $(\rho=0.343)$.

A statistically significant (at $\mathrm{P}<0.05$ relationship between individual types of modern pentathlon was determined.

Summing up the results of the correlation analysis (taking into account the results of the two World Championships), it can be argued that the closest positive relationship exists between the places occupied by athletes in fencing, as well as in a combined type and their places in the final protocol. As for the places occupied by athletes in horse riding and swimming, the relationship of this indicator with their final places is weak. It can be assumed that the correlation dependence between the places occupied by athletes in swimming and their final places depends on the composition of the participants. However, this assumption requires further verification.

\section{Conclusions.}

Optimal control of the training process is directly related to the development of effective models of competitive activity, structured on the basis of the analysis of the results shown by the leading athletes at major competitions. In the types of sports all-around it is 
recommended to use generalized, group and individual models.

Two types of group models of competitive activity in modern pentathlon have been determined. The first type is typical for a group of athletes who are mainly able to achieve high results in fencing, distinguished by a high level of speed-power and coordination abilities. The second one unites athletes who achieve high results in the combined type of modern pentathlon. Athletes whose competitive activity corresponds to the second type are inferior to the representatives of the first in the manifestation of speed-power potential and the development of coordination abilities, but they significantly surpass them in endurance.

This fact is confirmed by the presence of a close correlation relationship between the place taken in high-level competitions and the result in certain types of pentathlon.

At the same time, the highest coefficients are observed between the final result and the points scored in fencing and combined type.

Thus, specialists, coaches and athletes, while improving the pentathlon training system, should pay particular attention to fencing and increasing the effectiveness of running training, which, due to the change in the rules of the competition, can become a reserve for further growth of sports results. At the same time, one should take into account the individual characteristics of a particular allrounder and rely to a greater extent on his leading motor abilities. Such an organization of the training process, based on the constant consideration of the individual characteristics of each athlete, is most justified at the stage of higher sports achievements.

\section{Conflict of interests}

The authors declare no conflict of interests.

\section{Література}

1. Севдалев, С.В., Врублевский Е.П., Кожедуб М.С., Митусова Е.Д. (2020) Индивидуализация тренировочного процесса легкоатлеток, специализирующихся в беге на разные дистанции, на основе учета биоритмики их организма. Теория и практика физической культуры. №5. С. 83-85.

2. Vrublevskiy, E., Lashkevich, S., Gerkusov, A., Sevdalev, S. (2019) Modelling of the competitive activities of qualified female short-distance runners, taking into account their individual characteristics. Physical Education of Students. 6. 320-326.

3. Полищук, В. Д. (2001) Легкоатлетическое десятиборье. Киев. Науковий світ. 252 с.

4. Михайлов, В.М. (1988) Индивидуальная подготовка многоборок различной квалификации на основе использования модельных характеристик: автореферат дис. ... канд. пед. наук: 13.00.04 / В.М. Михайлов; Моск. обл. гос. ин-т физ. культуры. - пос. Малаховка (Моск. обл.), $24 \mathrm{c}$.

5. Габрысь, Т. (1990) Структура многолетней подготовки в женском легкоатлетическом семиборье : дис. ... канд. пед. наук 13.00.04 / Т. Габрысь. - M., $24 \mathrm{c}$.

6. Суханов, С.М. (2013) Строение соревновательного результата в легкоатлетическом семиборье. Ученые записки университета имени П.Ф. Лесгафта. № 10 (104). С. 162-166.

7. Добрынская, Н., Козлова, Е. (2013) Моделирование соревновательной деятельности как основа индивидуализации построения многолетней подготовки в легкоатлетическом многоборье (женщины). Наука в олимпийском спорте. № 3. C. 31-37.

8. Немцев, О.Б., Немцева, Н.А., Доронин, А.М.,

\section{References}

1. Sevdalev, S.V., Vrublevskiy, E.P., Kozhedub, M.S., Mitusova E.D. (2020) Individualization of the training process of female athletes specializing in running at different distances, based on taking into account the biorhythm of their body. Theory and practice of physical culture. No. 5. 83-85.

2. Vrublevskiy, E., Lashkevich, S., Gerkusov, A., Sevdalev, S. (2019) Modeling of the competitive activities of qualified female short-distance runners, taking into account their individual characteristics. Physical Education of Students. 6. 320-326.

3. Polishchuk, V.D (2001) Athletics decathlon. Kiev. Scientific world. 252 p. Olympic sports. No. 3. pp 31-37.

4. Mikhailov, V.M (1988) Individual preparation of multisport of various qualifications based on the use of model characteristics: thesis. Cand. ped. Sciences: 13.00.04 / V.M. Mikhailov; Moscow region state in-t of physical culture. - pos. Malakhovka (Moscow region), $24 \mathrm{p}$.

5. Gabrys, T. (1990) The structure of long-term training in the women's athletics heptathlon: dis. ... Cand. ped. Sciences 13.00.04 / T. Gabrys. - M., 24 p.

6. Sukhanov, S.M. (2013) The structure of the competitive result in the athletics heptathlon. Scientific notes of the P.F. Lesgaft. No. 10 (104). pp 162-166.

7. Dobrynskaya, N., Kozlova, E. (2013) Modeling of competitive activity as the basis for the individualization of building long-term training in athletics allaround (women). Science in Olympic sport. №3 pp 31-37.

8. Nemtsev, O.B., Nemtseva, N.A., Doronin, A.M., Skidan, M.N. (2018) Time trends of the structure of the competitive result in the women's athletics heptathlon. Scientific notes of the University named af- 
Скидан, М.Н. (2018) Временные тренды структуры соревновательного результата в женском легкоатлетическом семиборье. Ученые записки университета им. П.Ф. Лесгафта. № 7 (161). С. 197-202.

9. Мехрикадзе В.В., Славкина Е.В., Ермолаев Б.В. (2019) Взаимосвязь видов в женском легкоатлетическом семиборье. Вестник спортивной науки. № 2. С. 9-13.

10. Gassmann, F., Fröhlich, M., Emrich, E. (2016) Structural Analysis of Women's Heptathlon. Sports. - Vol. 4. - No. 12. Pp. 1-11.

11. Севдалев, С.В., Кожедуб, М.С., Гусинец, Е.В. (2020) Моделирование соревновательной деятельности высококвалифицированных спортсменок (на примере современного пятиборья). Эпоха науки. № 24. С. 332-341.

12. Севдалев, С.В., Нарскин, Г.И. (2021) Специфика соревновательной деятельности высококвалифицированных спортсменок, специализирующихся в современном пятиборье. Прикладная спортивная наука. No.1(13). 95-99.

13. Сергеев, А.И. (2020) Исследование многолетней практики соревновательной деятельности спортсменок в служебно-прикладных видах многоборий. Ученые записки университета им. П.Ф. Лесгафта. № 11 (189). С. 451-456.

14. Севдалев С.В., Кожедуб М.С., Гусинец Е.В. (2020) Моделирование соревновательной деятельности спортсменок высокой квалификации (на примере современного пятиборья). Эра науки. № 24. С. 332-341.

15. Sevdalev, S.V., Kozhedub, M. S. (2020) Modeling of the competitive activitie of highly qualified athletes specializing in the modern pentathlon. Наука i освіта: науково-проктичний журнал Південного наукового Центру НАПН Украіни, № 3. С. 125-131.

16. Платонов, В.Н. (2004) Система подготовки спортсменов в олимпийском спорте. Общая теория и ее практические приложения. Киев. Олимпийская литература. 808 с. ter P.F. Lesgaft. No. 7 (161). pp 197-202.

9. Mekhrikadze, V.V., Slavkina, E.V., Ermolaev, B.V. (2019) The relationship of species in the women's athletics heptathlon. Sports Science Bulletin. No. 2. pp 9-13.

10. Gassmann, F., Fröhlich, M., Emrich, E. (2016) Structural Analysis of Women's Heptathlon. Sports. Vol. 4. No. 12. pp 1-11.

11. Sevdalev, S.V., Vrublevskiy, E.P., Kozhedub, M.S. (2020) Features of construction of a training process at the precompetitive stage of preparation of qualified sportswomen specializing in the modern pentathlon. Physical culture, sport and health of the nation: scientific journal, Vinnitsa No. 9 (28). pp 244-252.

12. Sevdalev, S.V., Narskin, G.I. (2021) The specifics of the competitive activity of highly qualified female athletes specializing in modern pentathlon. Applied sports science. No.1(13). pp 95-99.

13. Sergeev, A.I. (2020) Research of long-term practice of sportswomen's competitive activity in serviceapplied types of all-round events. Scientific notes of the University named after P.F. Lesgaft. No. 11 (189). pp 451-456.

14. Sevdalev, S.V., Kozhedub, M.S., Gusinets, E.V. (2020) Modeling the competitive activity of highly qualified female athletes (on the example of modern pentathlon). The era of science. No. 24. pp 332-341.

15. Sevdalev, S.V., Kozhedub, M. S. (2020) Modeling of the competitive activity of highly qualified athletes specializing in modern pentathlon. Science and education: science and technology journal of the Pivdenny Science Center of the National Academy of Sciences of Ukraine, No. 3. pp 125-131.

16. Platonov, V.N. (2004) The system of training athletes in the Olympic sport. General theory and its practical applications. Kiev. Olympic literature. 808 p.

\section{Севдалев Сергей}

Учреждение образования «Гомельский государственный университет имени Франциска Скорины» г. Гомель, ул. Советская, 104, 246019, Республика Беларусь e-mail: sevdalev@mail.ru, тел.+375(29)6781809

\section{Врублевский Евгений}

Учреждение образования «Гомельский государственный университет имени Франциска Скорины» г. Гомель, ул. Советская, 104, 246019, Республика Беларусь

Зеленогурский университет, Зелена-Гура, Польша

e-mail: vru-evg@yandex.ru, тел. +375(29)3221139

\section{Алейник Евгений}

Учреждение образования «Гомельский государственный университет имени Франциска Скорины»

г. Гомель, ул. Советская, 104, 246019, Республика Беларусь

e-mail: Esenin.76@mail.ru, тел.+375(29)6799858

(C) Sevdalev S., Vrublevskiy E., 